\title{
Access, Care, Social Inequalities and The Pandemic COVID 19 In Brazil
}

\author{
Marcio Costa de Souza ${ }^{1 *}$ and Jairrose Nascimento Souza ${ }^{2}$ \\ ${ }^{1}$ Physiotherapist, Doctor of Medicine and Human Health, Professor in the Department of Life Sciences, State University of Bahia, \\ Brazil
}

${ }^{2}$ Physiotherapist, Public Health Specialist, Collaborating Researcher at the Micropolitics and Health Training Group, State University of Bahia

*Corresponding author: Marcio Costa de Souza, Department of Life Sciences, State University of Bahia, Street Silveira Martins, 2555, Bahia, Brazil

\begin{tabular}{l}
\hline ARTICLE INFO \\
\hline Received: 幽 October 29, 2020 \\
Published: 幽 November 02, 2020
\end{tabular}

Citation: Marcio Costa de S, Jairrose Nascimento S. Access, Care, Social Inequalities and The Pandemic COVID 19 In Brazil. Biomed J Sci \& Tech Res 31(4)2020. BJSTR. MS.ID.005125.

\begin{abstract}
The COVID 19 pandemic emerge in a global context that requires authorities to take emergency actions in planning and organizing to make access to health services effective in combating existing barriers evidenced in different systems and especially in countries with greater evidence of social inequities, the that refers to the need to expand knowledge and reflections on the reality of health care from the care network to the work processes that permeate them. That way, elements that showed interferences in mental health, racism, lack of communication and the $r$ effecting a subjective view of care is of fundamental importance.
\end{abstract}

\section{Short Communication}

COVID 19 emerges in the world at the end of 2019, in an intense way in Asia and is considered a Pandemic from March this year by the World Health Organization after it has spread to other continents. In addition to the spread of the disease, SARS-CoV-2, as the most serious pathological manifestation of that event was called, it initially reached a high number of deaths, mainly in the elderly and people with cardiovascular comorbidities, which demanded actions based on horizontal social distance, since pharmacological treatments and vaccines were not available to reduce the harmful action of the disease [1,2]. For this new challenge, it was necessary to act quickly to expand access to hard technologies [3] (equipment and procedures) and highly complex services, with the creation of care spaces that met the need presented by the severity of respiratory cases, that consequently, need intensive care units and mechanical respirators, able to resolve the pathophysiological effects of SARS-VOC-2, even with difficulties, as they do not have parameters that would effectively direct [4].

Regarding this discussion on access in countries where social inequalities are more evident, there are even in universal systems like Brazil, obstacles that directly interfere in the resolution of health care, it is necessary to analyze under the aegis of the barriers of geographical, economic, functional and communicational access [5]. In Brazil, stimulated by social inequities, geographical and economic barriers to access are elements that interrupt health care, and was seen in the initial process of the disease, when it reached the north and northeast regions, which shows in the negative results in the high prevalence of indigenous, black and brown people with COVID 19, and automatically, a high mortality rate, revealing the existing social divide $[6,7]$.

Another evidenced difficulty of access is the functional nature [5], that due to the lack of knowledge about the disease and the deficit of health services able to specifically assist, contribute to patients, when exceeding the limits imposed by geographic and economic nature, to have an afflicted action when arriving at a health unit, producing ineffective therapeutic itineraries with no resolution, causing in many cases an increase in the severity of the disease and consequently death. Therefore, it is of fundamental importance to think and act in the construction of lines of care that go beyond the high complexity with the formation of a care 
network, which connect the three levels of organization of health services, especially Primary Health Care. It also stands out, you need to have a different look at health care in Post-COVID, as the patients affected in the most severe form of the pathology for the most part present several sequelae that demand continuous care [8]. Notwithstanding, providing policies that encourage permanent education processes based on interprofessionality are essential, and have as a goal the improvement of the health professional, directing a user-centered health care with a focus on teamwork, and that can solve the illnesses of those in need $[9,10]$.

However, a dimension that also needs to be discussed, is communicational access [5], which establishes a production of health care in the field of micropolitics based on human relations, with a subjective view from the reception, horizontal dialogue and construction of bonds (light technologies of care) [3], elements that were minimized in the face of the need for social distance and extreme care to reduce contamination of the disease and damage caused by it. Although, it should be noted that, this need demanded a maximum effort from health professionals, to allow a more humanized and integral care, in this context we realize that the mental health of workers are being affected, as well as that of patients and family, because relationships are healthy activities for the development of human nature and make up the broadest form of health care $[7,11]$. In the field of macropolitics, there were constant actions of disinformation processes [6], which directly affects health care, especially with a view to the communication barrier, with the distribution of fake news about scientifically unproven health treatments, in an attempt to underestimate and minimize the disease. That way, the referred Pandemic had several implications to guarantee access to health services to the world population, but with some singularities in Brazil, which need to be revealed and reflected by all social strata. Among those presented, we highlight the delay in health planning actions to combat the spread of COVID 19 and its serious manifestation of SARS-COV-2, which resulted in a high number of infected, deaths and sequelae [6].

\section{Final Considerations}

The barriers of access, both geographic and economic, reveal the great social inequity that still exists, the aftermath of a social construction based on colonialism with 350 years of enslaved blacks and the decimation of indigenous indigenous peoples. These peoples currently live mostly in the northeastern and northern regions of Brazil, which has shown a higher prevalence and mortality rate among blacks, browns and indigenous people. The health services showed a great resolving incapacity when faced with this situation, which was evidenced from meeting the functional needs, both in terms of the specific care of the disease, as well as from elements of daily life in the field of personal relationships, between professional-patient, which in addition to the effectiveness of care, can contribute to the self-care of workers, especially in their mental health.

\section{References}

1. Lurie N, Saville M, Hatchett R, Halton J (2020) Developing Covid-19 Vaccines at Pandemic Speed. N Engl J Med 382(21): 1969-1973.

2. Bedford J, Enria D, Giesecke J, Heymann DL, Ihekweazu C, et al. (2020) COVID-19: towards controlling of a pandemic. Lancet 395(10229): 1015-1018.

3. Franco TB, Merhy EE (2012) Cartografias do trabalho e cuidado em Saúde. Tempus - Actas de Saúde Coletiva 6(2): 151-163.

4. Noronha KVMS, Guedes GR, Turra CM, Andrade MV, Botega L, et al. (2020) The COVID-19 pandemic in Brazil: analysis of supply and demand of hospital and ICU beds and mechanical ventilators under different scenarios. Cad Saúde PúbliCA 36(6): e00115320.

5. Souza MC (2006) Modelos de Atenção no Cetrno de Saúde Parque Floresta - Alagoinhas Bahia. Dissertation. Master in Public Health. State University of Feira de Santana, Brazil.

6. Hallal PC, Hartwig FP, Horta BL, Silveira MF, Struchiner CJ, et al. (2020) SARS-CoV-2 antibody prevalence in Brazil: results from two successive nationwide serological household surveys. The Lancet 8(11): E1390-E1398.

7. Goes EF, Ramos DO, Ferreira AJF (2020) Racial health inequalities and the COVID-19 pandemic. Trab educ Saúde 18(3): e00278110.

8. Portela MC, Grabois V, Travassos C (2020) Matriz linha de cuidado Covid-19 na rede de atenção à saúde. Observatório Covid-19, Fiocruz.

9. Souza MC (2019) Redes de Cuidado em pessoas com doenças respiratórias crônicas (Thesis). PhD in Medicine and Human Health. Bahiana School of Medicine and Public Health, Brazil.

10. Quintana RAC, Souza ICS, Pereira JM, Pires RA, Lima RSGS, et al. (2020) Production of Interprofessional Care for the Person with Oncological Disease: A Study on the Patient's Perspective. Biomedical Journal of Scientific and Technical Research 29(3): 22413- 22418.

11. Damasceno KCS, Merces MC (2020) COVID-19 e a saúde mental dos trabalhadores de saúde da atenção básica. Enfermagem Brasil 19(4): S1-S2. 


\section{ISSN: 2574-1241}

DOI: 10.26717/BJSTR.2020.31.005125

Marcio Costa de Souza. Biomed J Sci \& Tech Res

(C) This work is licensed under Creative

Submission Link: https://biomedres.us/submit-manuscript.php

$\begin{array}{ll}\text { BIOMEDICAL } & \text { Assets of Publishing with us } \\ \text { RESEARCHES } & \text { - Global archiving of articles } \\ \text { - Immediate, unrestricted online access }\end{array}$

